\title{
A Review of Performance Appraisals of Nigerian Federal Government-Owned Refineries
}

\author{
Ismaila Badmus, Miracle Olanrewaju Oyewola, Richard Olayiwola Fagbenle \\ Mechanical Engineering Department, University of Ibadan, Ibadan, Nigeria \\ Email: akinbadmus@yahoo.com
}

Received November 12, 2011; revised December 18, 2011; accepted December 23, 2011

\begin{abstract}
The aim of this paper is to review previous works on the performance appraisal of Nigerian government-owned refineries. The review has been done in a general sense, covering appraisal works by engineers, scientists, management experts, economists, sociologists and even historians. The outcome indicates that while there seems to be several works directly and/or indirectly assessing the performance of the refineries in a general sense, there is a dearth of such in the specific area of energy consumption. There also appears to be no single one appraising energy utilisation of all the refineries at the same time in the open literature. This is in spite of the fact that refining processes are energy intensive. Despite popularisation of exergy analysis as a veritable tool, the only energy utilisation appraisal within our reach which was carried out on just one of the refineries has not been done exergetically. However, the work still reveals, within the limitations of $1^{\text {st }}$ Law energy analysis that the energy consumption patterns are below international benchmarks in the oil and gas industry. Some suggestions have also been offered to take care of the energy efficiency challenges in these refineries. These include plant to plant analyses of energy utilisation patterns in the four refineries, periodical determination of GHG emission levels in the refineries using current international best practices as benchmarks, use of exergy analysis to check avoidable energy wastage in the refining processes, shifting refinery fuelling pattern in favour of low carbon content fuels like natural gas and ensuring regular turnaround maintenance of the system.
\end{abstract}

Keywords: Nigerian Refineries; Energy Efficiency; Exergy Analysis; Review; Performance Appraisal

\section{Introduction}

Nigeria is endowed with a vast amount of energy resources. According to the OPEC annual statistical bulletin 2009 [1], Nigeria proven crude oil reserves and natural gas are 37.2 billion barrels and 5292 trillion standard cubic metres, respectively. Nigerian oil attracts a lot of buyers in the international market. The major reason for this is because Nigerian oil is of high quality and most environmentally friendly relative to oil from other countries. Nigeria's export blends are light, sweet crudes and have low sulphur contents of $0.05 \%-0.2 \%$ [2].

The country is the eleventh largest producer and the eighth largest exporter of crude oil in the world. It typically produces over 2.4 million barrels per day (b/d) of oil and natural gas liquids [3]. Unfortunately, for about the past one decade, only $17 \%-20 \%$ of domestic gasoline demand could be supplied by local refineries $[4,5]$.

Due to the fact that energy is a factor that touches every aspect of human existence, everyone has been naturally concerned about the deplorable state of the Nigerian energy sector. Different researchers have tried to tackle the challenge, based on their intellectual view- points. These include economists, sociologists, engineers, scientists, management experts and even historians. They are practically unanimous on the fact that all is not well in the industry.

For instance, Eti et al. [6] assessed management of the Nigerian petrochemical industry, in polypropylene production, using Port Harcourt Refining Company as a case study and concluded that the poor performance has been due to "traditional but outmoded indigenous industrial and commercial policies and practices”. Nwosu et al. [7] believe that most Nigerians have not benefited from the vast financial investments that have been made in the upstream crude-oil and natural-gas sector in Nigeria because the associated major activities remain primarily controlled and managed by foreign multi-national companies. They suggest a wiser balance between globalisation and localisation. However, Nwokah and Ezirim [8] opine that the joint venture arrangement with multinational oil companies to increase crude oil production and to make use of foreign expertise available in the industry is not performing badly, although the basis of their conclusion, which was responses from the benefiting oil companies, may not be strong enough. Nobody expects 
them to bite the finger that feeds them! Observed from any perspective, one undisputable fact is that the fuel supply shocks are unbearable to the Nigerian economy.

\section{The General State of Nigerian Government-Owned Refineries}

The Nigerian Federal Government, through its company, the Nigerian National Petroleum Corporation (NNPC), owns the four existing crude oil refineries in Nigeria. The four refineries include Warri Refinery and Petrochemical Company (WRPC), Old Port Harcourt Refinery, The New Port Harcourt Refinery and Petrochemical Company (PHRC) and Kaduna Refinery and Petrochemical Company (KRPC), with a combined installed capacity of 445,000 barrels per day. Each of these refineries is a subsidiary company under the management of the NNPC. Table 1 provides pertinent details on each of these refineries including their nameplate capacities and years of commissioning.

Petroleum products have, for some two decades now, been supplied to the Nigerian market from two sources: domestic crude oil refineries and imports. The split between the two modes was heavily dependent on the availability of the domestic crude oil refining facilities.

The inability of the NNPC refineries to meet local demand for petroleum products especially the premium motor spirit, has translated to a heavy reliance of the Federal government of Nigeria on importation to meet local demands. Table 2 provides information on quantities of petroleum products supplied from these two sources during the period 1980-2006. It is observable that the year with least petroleum products importation was 1991 with $0.4 \%$ and the worst year in this case was 2000 with $73.7 \%$ importation.

Despite the importation to augment local production, the local consumption of petroleum products in the country is low. These refineries are currently unable to meet domestic demand of 300,000 barrels of oil per day. In an opinion poll conducted by Adenikinju and Falobi [10], as presented in Table 3, it is seen that most respondents believed that good working conditions of Nigerian refineries are a necessary prelude to continuous hitch-free

Table 1. Crude oil refining capacity in Nigeria.

\begin{tabular}{ccc}
\hline Plant & $\begin{array}{c}\text { Date of } \\
\text { commissioning }\end{array}$ & $\begin{array}{c}\text { Installed capacity } \\
\text { (barrels/day) }\end{array}$ \\
\hline Old P/Harcourt & 1965 & 60,000 \\
New P/Harcourt & 1989 & 150,000 \\
Warri & 1978 & 125,000 \\
KADUNA & 1980 & 110,000 \\
& & 445,000 \\
\hline
\end{tabular}

Table 2. Petroleum product supplies in Nigeria.

\begin{tabular}{|c|c|c|c|c|}
\hline Years & $\begin{array}{c}\text { Imported } \\
\text { Quantities } \\
\text { (Million Tonnes) }\end{array}$ & $\begin{array}{l}\text { Local Refineries } \\
\text { Supplies } \\
\text { (Million Tonnes) }\end{array}$ & $\begin{array}{l}\text { Total (Million } \\
\text { Tonnes) }\end{array}$ & \% Imported \\
\hline 1980 & 2.46 & 4.45 & 6.91 & 35.6 \\
\hline 1981 & 2.08 & 6.15 & 8.23 & 25.3 \\
\hline 1982 & 2.05 & 8.29 & 10.34 & 19.8 \\
\hline 1983 & 3.60 & 7.18 & 10.78 & 33.4 \\
\hline 1984 & 2.68 & 6.20 & 8.88 & 30.2 \\
\hline 1985 & 2.59 & 6.41 & 9.00 & 28.8 \\
\hline 1986 & 2.89 & 9.07 & 11.96 & 24.2 \\
\hline 1987 & 2.81 & 5.84 & 8.65 & 32.5 \\
\hline 1988 & 1.59 & 7.01 & 8.60 & 18.5 \\
\hline 1989 & 2.05 & 8.23 & 10.28 & 19.9 \\
\hline 1990 & 0.93 & 8.67 & 9.60 & 9.7 \\
\hline 1991 & 0.03 & 8.04 & 8.07 & 0.4 \\
\hline 1992 & 2.15 & 8.56 & 10.71 & 20.1 \\
\hline 1993 & 3.20 & 7.29 & 10.49 & 30.5 \\
\hline 1994 & 2.79 & 5.44 & 8.23 & 33.9 \\
\hline 1995 & 1.51 & 6.72 & 8.23 & 18.3 \\
\hline 1996 & 2.36 & 5.44 & 7.80 & 30.3 \\
\hline 1997 & 1.25 & 6.92 & 8.17 & 15.3 \\
\hline 1998 & 3.69 & 5.09 & 8.78 & 42.0 \\
\hline 1999 & 2.64 & 5.36 & 8.00 & 33.0 \\
\hline 2000 & 7.26 & 2.59 & 9.85 & 73.7 \\
\hline 2001 & 4.47 & 6.77 & 11.24 & 39.8 \\
\hline 2002 & 4.54 & 6.86 & 11.40 & 39.8 \\
\hline 2003 & 7.18 & 7.30 & 14.48 & 49.6 \\
\hline 2004 & 6.50 & 6.31 & 12.81 & 50.7 \\
\hline 2005 & 6.15 & 9.39 & 15.54 & 39.6 \\
\hline 2006 & 6.49 & 6.08 & 12.57 & 51.6 \\
\hline
\end{tabular}

Source: NNPC Annual Statistical Bulletins (2003-2006) quoted in Dayo [9].

supply of petroleum products.

Indeed, the refineries have been assessed by a lot of researchers, paying attention to different aspects.

Looking at the degree of environmental friendliness, Ibitoye and Akinbami [11] observe that lack of access to appropriate technology, as well as inappropriate energy-pricing policies, among others are some of the barriers against viable $\mathrm{CO}_{2}$ mitigation options in the energy 
sector. The options include the introduction of efficiency

Table 3. Causes of fuel scarcity by respondent group (\%).

\begin{tabular}{lcccccc}
\hline \multicolumn{1}{c}{ Cause } & Marketers & Attendants & Hawkers & Vehicle Owners & Commuters & Businesses \\
\hline Breakdown of refineries & 52.9 & 44.7 & 47.2 & 47.4 & 35.9 & 42.1 \\
High import cost & 17.6 & 28.9 & 0.0 & 7.9 & 10.3 & 2.6 \\
Political factors & 11.8 & 7.9 & 50.0 & 18.4 & 43.6 & 34.2 \\
Inefficiency of NNPC & 17.6 & 18.4 & 2.8 & 18.4 & 10.3 & 21.1 \\
Price too low & 0.0 & 0.0 & 0.0 & 7.9 & 0.0 & 0.0 \\
\hline
\end{tabular}

measures in the energy-supply route as well as in the end-use sectors of the energy system (i.e. electric-power generation, refineries, extraction processes as well as in the residential, industrial, agricultural, transportation and the commercial sub-sectors). Ogunleye [12] details the negative environmental impact of oil on Nigeria as environmental pollution, gas flaring, oil spillages and leakages, refinery effluents and oil-related fires and explosions. On the whole, the forest and land degradation lead to loss in soil fertility; polluted water makes drinking water unsafe and results in species' extinction; constant gas flaring and other oil-related effluents combine to assault the livelihoods of most oil communities without adequate compensation by the multinational oil companies or the government. Indeed, Sathaye and Ravindranath [13] categorically state that reduction of gas flaring in the Nigerian oil industry has been identified as a key component in achieving percentage reductions in future GHG emissions. On volatile organic compounds (VOCs), Sonibare et al. [14] used the "no-control-measure" option to estimate VOCs from the existing 4 petroleum refineries located in the states of Delta, Kaduna, and Rivers as 147,212 ton/annum (if operated at full capacity), noting that the southern part of the country is at a great risk of VOC emission from petroleum refineries. Also, in an analysis carried out by Israel et al. [15] on government owned Eleme Petrochemical Company Limited, effluents and soil samples where sediments from the treated effluents are dumped were analysed for physicochemical properties, metallic and non-metallic ions and compared with established international standard (FEPA). Although the petrochemical effluents contained very high concentration of Total Dissolved Solids (284.00 \pm $0.14 \mathrm{mg} / \mathrm{L}$ ), they were still found to be within FEPA effluent limitations for guidelines of $2000 \mathrm{mg} / \mathrm{L}$ for Petroleum Refinery, Fuel/Gasoline oil category in Nigeria.

Concerning capacity utilisation, as observed earlier [5], the government owned refineries have hardly operated above $40 \%$ capacity utilization rate for any extended period of time in the past two decades.

Low capacity utilisation has been the special bane of our refineries. As indicated earlier, the refinery capacity of the country is $445,000 \mathrm{bpd}$, making her theoretically self-sufficient in domestic oil consumption. The gap between refinery capacity and refinery output is a reflection of the poor state of domestic refineries. Table 4 [10] provides a succinct summary of the state of Nigerian refineries. The performance of the crude distillation units (CDU) and fluid catalytic cracking unit (FCC) in the three refineries remains poor and well below international standards.

The poor state of facilities in the refineries is a major contribution to the present fuel crisis. All the refineries are at present producing below capacity.

\subsection{Turn around Maintenance (TAM)}

On African refineries in general, de Gouvello et al. [16] reported that only 7 of the region's operating refineries can be classified as world scale: Nigeria (3), South Africa (3), and Sudan (1). All other refining capacities across the region are regarded as "kettles". Another key barrier to project implementation is that many existing refineries in these countries run at low-capacity utilization. Improperly implemented maintenance has resulted in frequent breakdowns of facilities, resulting in high levels of product imports to meet domestic demand. The refining facilities in Nigeria exemplify this situation.

Table 4. Efficiency indicators of Nigerian refineries, 1996.

\begin{tabular}{lcccc}
\hline & PHRC 1 & WRPC & KRPC & PHRC 2 \\
\hline Year of establishment & 1965 & 1980 & 1980 & 1989 \\
Capacity (TBD) & 60 & 125 & 110 & 150 \\
Operating capacity (\%) & - & 52 & 47 & 58 \\
Unit capacity utilization (\%) & & & & \\
CDU & - & 52 & 47 & 58 \\
FCC & - & 55 & 47 & 26 \\
Unit time efficiency (\%) & & & & \\
CDU & - & 31 & 94 & 58 \\
\hline
\end{tabular}


FCC 23 70 26

$\mathrm{TBD}=$ Thousand barrels per day; $\mathrm{CDU}=$ Crude distillation unit; FCC = Fluid catalytic cracking unit.

The failure of the Nigerian National Petroleum Company (NNPC) management to effect regular turnaround maintenance (TAM) on the various plants to prevent a breakdown and sustain high capacity utilization has been the major problem facing the refineries [17]. A TAM overhaul of the refineries is recommended to be carried out every 18 or 24 months. Odigure et al. [18] investigated quality of water used in boilers of Refining Companies in Nigeria. The results show that the quality of water fed to the boilers is off specification. Low water quality used in boilers is observed to have led to frequent failure of the boilers as a result of tube rupture. The poor performance of the boiler feed treatment plant is attributable to the deplorable condition of water intake plant, raw water treatment, demineralization plant, change in raw water quality and non-functioning of the polisher unit. Poor maintenance of the Nigerian governmentowned refineries led to a drastic fall of production level to $15 \%$ of the total installed capacity in 2004 . The sudden closure of the Kaduna and Warri refineries during this period to allow for the turnaround maintenance (TAM) contributed to the decrease in production [19].

\subsection{Gas Flaring}

Gas flaring degrades both energy and the environment. Unfortunately, Nigeria flares an average of 22 billion cubic metres of natural gas annually as a by-product of petroleum exploitation. When 10 out of the over 300 gas flare sites were monitored, about a decade ago, it was discovered that the energy equivalent of the gas was greater than the total electric power generated in the country for any given period at 30\% fuel conversion [20]. According to Kennedy-Darling et al. [21], it is estimated that significantly more than half of Nigeria's natural gas is given off as flares. Thus, a huge amount of valuable fuel is simply burned off.

\subsection{General Decline in Technical Efficiency}

Practically all researchers believe there is a general decline in the level of technical efficiency at which Nigerian refineries operate. Naturally, inadequate system maintenance and technological obsolescence would lead to a general decline in technical efficiency of a system. Hence, poor and irregular turn around maintenance as well as outmoded industrial practices are possible causes of this general decline in technical efficiency. Perhaps this is why even social scientists like Bamisaye and Obiyan [22] have also advocated urgent repair of Nigeria's oil refineries.

\subsection{Energy Utilisation}

Jesuleye et al. [23] analysed energy demand of PortHarcourt refinery, Nigeria, based on information obtained from its annual publications, backed-up by spot interviews. The analytical approach adopted for the study involves the calculation of energy intensities to determine the refinery's annual energy demand for various energy types considered from 1989 to 2004. The results showed that the actual energy demand per year for processing crude oil into refined products, exceeded, in varying degrees the stipulated refinery standard of 4 barrels of oil equivalent (BOE) per 100 BOE. It varied from 4.28 8.58 BOE per $100 \mathrm{BOE}$. In terms of energy demand efficiency, this implies very poor performance of the refinery during the 16-year period under investigation. The excess demand which translates to an average daily wastage of about 2005 BOE is estimated to be $\$ 56,196$ (US Dollars) based on the 2003 OPEC basket price of \$28.0213 per barrel. Lack of optimal fuel utilization-mix and non-compliance with the Turn-Around-Maintenance schedules were attributed to the refinery's inefficient energy demand pattern.

\section{Observations}

- Despite apparent preponderance of studies on general assessment of Nigerian refineries in the open literature, only this recent one by Jesuleye et al. appears to be an in-depth energy analysis of only one of the refineries.

- Besides, this work uses only one of the standard approaches to assess the energy utilisation pattern. For instance, according to Ocic [24], the share of crude oil used for energy generation in oil refineries nowadays is in the range of $4 \%$ to $8 \%$, depending on the refinery complexity level. Complexity, i.e. "a depth of crude-oil processing” is increased as the range of products and the number of so-called secondary units is enlarged. In particular, the level of energy requirement in an oil refinery is increased by the level of complexity and it is expressed as either the share of energy consumption in total quantity of crude-oil processed, or as specific energy consumption per tonne of processed crude oil, or per tonne of generated refinery products. Hence, the level of energy requirement is increased by the level of complexity and that the oil refineries with the same level of complexity can have low and high level of energy efficiency. Indeed, the level of energy requirement can be as low as $2 \%$ of the total crude processed [25].

- It is apparently "natural" that a researcher requesting for more detailed data than NNPC is ready to provide may be embarking on a difficult task. This is because 
as the overseer of the nation's interest in the oil and gas industry, NNPC is central to the Nigerian economy. The level of security surrounding anything oil and gas, including the refineries, is sometimes higher than that around the military formations [26]. Hence, it is not that surprising that Jesuleye et al. had the challenge of "paucity of data", as reported in the work, while conducting the research.

- In particular, one expects them to also use the second type of efficiency assessment, i.e.—“as a specific energy consumption per tonne of generated refinery products".

- Furthermore, the work observes that "the refinery energy demand mix (by type of fuel use) did not follow the most technically efficient path", but does not state this "most technically efficient path" explicitly.

- Considering the fact that the refinery under study was at least 15 years old at the time of the research and the design standard around 1989 may be below the currently obtainable benchmark in the refining industry, it may also be necessary to compare the performance with the current standards and not the one of 1989.

- Finally, one veritable tool in assessing energy utilisation patterns of thermodynamic systems these days is exergy analysis [27-32]. Although the tool has been used in the same industry elsewhere [33,34], it has not been used in the work by Jesuleye et al.

\section{Conclusions and Outlook}

Having carried out a general review of performance appraisals of Nigerian government-owned refineries, it is discovered that only one research article out of about twenty reviewed, forming a very small percentage of 5\%, is directly on refining processes energy consumption by the refineries. This is despite the fact that refining processes are generally energy intensive. Besides, this only work on refining processes energy consumption by the refineries has not been done using exergy analysis as a tool. Hence:

1) In order to know the real state of affairs in the refineries, it is necessary to analyse the plant to plant energy utilisation patterns in the four refineries. This will facilitate optimisation of the energy utilisation in the refineries using international best practices as benchmarks.

2) It is also necessary to determine, periodically, the GHG emissions in order to reduce their production in our refineries using the current international best practices as benchmarks.

3) It is equally important to check avoidable wastage of energies in the refining processes in our petroleum industry. To do this an exergetic approach is strongly recommended due to its tested and reliable effectiveness in other places.
4) It is necessary to formulate appropriate policies to stabilise prices of petroleum products that have always been soaring as a result of poor performance of our local refineries. In addition, a good approach to pricing is to cost the heating values of the products, since this is what the consumers actually pay for.

5) Refinery fuelling should be in favour of low carbon content fuels like natural gas. This, in the Nigerian case, will also check energy and environmental degradation caused by gas flaring.

6) The importance of regular maintenance cannot be over-emphasised as a poorly maintained system will naturally consume more energy for the same output.

7) Nationwide general awareness on energy conservation needs and measures is necessary so that all and sundry can be energy-efficiency conscious.

\section{REFERENCES}

[1] Organisation of Petroleum Exporting Countries (OPEC), “Oil and Gas Data," OPEC Annual Statistical Bulletin, Vienna, 2009, pp. 22-23.

[2] G. O. Odularu and C. Okonkwo, "Does Energy Consumption Contribute to Economic Performance? Empirical evidence from Nigeria," Journal of Economics and International Finance, Vol. 1, No. 2, 2009, pp. 44-58. http://www.academicjournals.org/JEIF

[3] M. Watts, "Crude Politics: Life and Death on the Nigerian Oil Fields," Niger Delta Economies of Violence Working Papers, Institute of International Studies, University of California, Berkeley, The United States Institute of Peace, Washington, DC, Paper No. 25, 2009.

[4] H. Obih, "Fuel Distribution and Logistics," Sub-Regional Conference on the Phase-Out of Leaded Gasoline in Nigeria \& Neighbouring Countries, Abuja, 15-16 November 2001

[5] A. Iwayemi, "Nigeria's Dual Energy Problems: Policy Issues and Challenges," Proceedings of 31st International Conference of International Association for Energy Economics, Istanbul, 18-20 June 2008, pp. 17-21.

[6] M. C. Eti, S. O. T. Ogaji and S. D. Probert, "Petrochemical Industry in Nigeria: A Performance Appraisal,” Applied Energy, Vol. 79, No. 1, 2004, pp. 97-107. doi:10.1016/j.apenergy.2003.10.006

[7] H. U. Nwosu, I. N. Nwachukwu, S. O. T. Ogaji and S. D. Probert, "Local Involvement in Harnessing Crude Oil and Natural Gas in Nigeria,” Applied Energy, Vol. 83, No. 11, 2006, pp. 1274-1287. doi:10.1016/j.apenergy.2005.09.001

[8] N. G. Nwokah and A. C. Ezirim, "The Effect of Joint Venture Arrangement on the Production and Distribution of Petroleum Products in Nigeria,” International Bulletin of Business Administration, Vol. 5, 2009, pp. 28-36. http://www.eurojournals.com/IBBA.htm

[9] F. B. Dayo, "Clean Energy Investment in Nigeria the Domestic Context, a Country Case Study,” International 
Institute for Sustainable Development's Clean Energy Investment Project, Manitoba, 2008. http://www.iisd.org

[10] A. F. Adenikinju and N. Falobi, "Macroeconomic and Distributional Consequences of Energy Supply Shocks in Nigeria,” AERC Research Paper 162, African Economic Research Consortium, Nairobi, 2006.

[11] F. I. Ibitoye and J.-F. K. Akinbami, "Strategies for Implementation of $\mathrm{CO}_{2}$ Mitigation Options in Nigeria's Energy Sector”, Applied Energy, Vol. 63, No. 1, 1999, pp. 1-16. doi:10.1016/S0306-2619(99)00015-X

[12] E. K. Ogunleye, "Natural Resource Abundance in Nigeria: From Dependence to Development," Resources Policy, Vol. 33, No. 3, 2008, pp. 168-174. doi:10.1016/j.resourpol.2008.03.002

[13] J. A. Sathaye and N. H. Ravindranath, "Climate Change Mitigation in the Energy and Forestry Sectors of Developing Countries," Annual Review of Energy and the Environment, Vol. 23, 1998, pp. 387-437. doi:10.1146/annurev.energy.23.1.387

[14] J. A. Sonibare, F. A. Akeredolu, E. O. Obanijesu and F. M. Adebiyi, "Contribution of Volatile Organic Compounds to Nigeria’s Air-Shed by Petroleum Refineries," Petroleum Science and Technology, Vol. 25, No. 4, 2007, pp. 503-516. doi:10.1080/10916460500295397

[15] A. U. Israel, I. B. Obot, S. A. Umoren, V. Mkpenie and G. A. Ebong, "Effluents and Solid Waste Analysis in a Petrochemical Company-A Case Study of Eleme Petrochemical Company Ltd, Port Harcourt, Nigeria,” CODEN ECJHAO E-Journal of Chemistry, Vol. 5, No.1, 2008, pp. 74-80.

[16] C. de Gouvello, F. B. Dayo and M. Thioye, "Low-Carbon Energy Projects for Development in Sub-Saharan Africa Unveiling the Potential, Addressing the Barriers," Norwegian Trust Fund for Private Sector and Infrastructure, The International Bank for Reconstruction and Development/The World Bank, Washington DC, 2008. www.worldbank.org

[17] E. E. Okafor, "Rethinking African Development: A Critical Overview of Recent Developments in the Petroleum Sub-Sector in Nigeria," Kamla-Raj Journal of Social Sciences, Vol. 15, No. 1, 2007, pp. 83-93.

[18] J. O. Odigure, A. S. Abdulkareem and E. T. Asuquo, "Effect of Water Quality on the Performance of Boiler in Nigerian Petroleum Industry,” Leonardo Electronic Journal of Practices and Technologies, Vol. 4, No. 7, 2005, pp. 41-48.

[19] I. Aigbedion and S. E. Iyayi, "Historical Review: Diversifying Nigeria’s Petroleum Industry,” International Journal of Physical Sciences, Vol. 2, No. 10, 2007, pp. 263-270. http://www.academicjournals.org/IJPS

[20] P. N. Ede and G. A. Johnson, "Energy Relations of Gas Estimated from Flare Radiation in Nigeria,” International Journal of Energy Research, Vol. 25, No. 1, 2001, pp. 8591.

doi:10.1002/1099-114X(200101)25:1<85::AID-ER651>3 .0.CO;2-B

[21] J. Kennedy-Darling, N. Hoyt, K. Murao and A. Ross, "The Energy Crisis of Nigeria: An Overview and Impli- cations for the Future,” The University of Chicago, Chicago, 2008.

[22] O. A. Bamisaye and A. S. Obiyan, "Policy Analysis of Oil Sector in Nigeria," European Journal of Social Sciences, Vol. 3, No. 1, 2006, pp. 37-48.

[23] O. A. Jesuleye, W. O. Siyanbola, S. A. Sanni and M. O. Ilori, "Energy Demand Analysis of Port-Harcourt Refinery, Nigeria and Its Policy Implications,” Energy Policy, Vol. 35, No. 2, 2007, pp. 1338-1345. doi:10.1016/j.enpol.2006.04.004

[24] O. Ocic, "Oil Refineries in the 21st Century: Energy Efficient, Cost Effective, Environmentally Benign,” WILEYVCH Verlag GmbH \& Co. KGaA, Weinheim, 2005.

[25] M. Bagajewicz and S. Ji, "Rigorous Procedure for the Design of Conventional Atmospheric Crude Fractionation Units. Part I: Targeting,” Industrial \& Engineering Chemistry Research, Vol. 40, No. 2, 2001, pp. 617-626. doi:10.1021/ie000302+

[26] G. U. Nwokeji, “The Nigerian National Petroleum Corporation and the Development of the Nigerian Oil and Gas Industry: History, Strategies and Current Directions," The James A. Baker III Institute for Public Policy, Rice University, Houston, 2007.

[27] C. J. Diji, "Energy-Exergy Analysis and Carbon(IV) Oxide Emission Estimation of the Cement Manufacturing Industry in Nigeria,” Ph.D. Thesis, University of Ibadan, Ibadan, 2007.

[28] E. Sciubba and G. A. Wall, "Brief Commented History of Exergy from the Beginnings to 2004," International Journal of Thermodynamics, Vol. 10, No. 1, 2007, pp. 126.

[29] A. N. Anozie, F. N. Osuolale and A. S. Osunleke, "Exergy Analysis of Binary Plate Distillation Operations," International Journal of Exergy, Vol. 6, No. 5, 2009, pp. 715-728. doi:10.1504/IJEX.2009.027498

[30] I. Badmus and A. S. Osunleke, “Application of Energy and Exergy Analyses for Efficient Energy Utilisation in the Nigerian Residential Sector,” International Journal of Exergy, Vol. 7, No. 3, 2010, pp. 352-368. doi:10.1504/IJEX.2010.031989

[31] D. A. Fadare, D. O. Nkpubre, A. O. Oni, A. Falana, M. A. Waheed and O. A. Bamiro, "Energy and Exergy Analyses of Malt Drink Production in Nigeria,” Energy, Vol. 35, No. 12, 2010, pp. 5336-5346. doi:10.1016/j.energy.2010.07.026

[32] R. L. Fagbenle, A. B. C. Oguaka and O. T. Olakoyejo, “A Thermodynamic Analysis of a Biogas-Fired Integrated Gasification Steam-Injected Gas Turbine (BIG/STIG) Plant," Applied Thermal Engineering, Vol. 27, No. 13, 2007, pp. 2220-2225. doi:10.1016/j.applthermaleng.2005.07.027

[33] A. B. Araujo, R. P. Brito and L. S. Vasconcelos, "Exergetic Analysis of Distillation Processes-A Case Study," Energy, Vol. 32, No. 7, 2007, pp. 1185-1193. doi:10.1016/j.energy.2006.07.003

[34] R. Rivero, "Application of the Exergy Concept in the Petroleum Refining and Petrochemical Industry,” Energy Conservation and Management, Vol. 43, No. 9-12, 2002, pp. 1199-1220. doi:10.1016/S0196-8904(02)00008-0 
Energy and Power Engineering, 2012, 4, 47-52

http://dx.doi.org/10.4236/epe.2012.41007 Published Online January 2012 (http://www.SciRP.org/journal/epe)

Scientific

Research 